Proc. Estonian Acad. Sci. Biol. Ecol., 2001, 50, 3, 180-193

\title{
HISTORY OF HYDROLOGICAL AND BIOLOGICAL INVESTIGATIONS OF LAKE VÕRTSJÄRV
}

\author{
Peeter NÕGES ${ }^{\mathrm{a}, \mathrm{b}}$, Andu KANGUR ${ }^{\mathrm{a}}$, Ain JÄRVALT ${ }^{\mathrm{a}}$, and Tiina NÕGES ${ }^{\mathrm{a}, \mathrm{b}}$ \\ ${ }^{a}$ Võrtsjärv Limnological Station, Institute of Zoology and Botany, Estonian Agricultural University, \\ 61101Rannu, Tartumaa, Estonia; pnoges@zbi.ee, akangur@zbi.ee, ajarvalt@zbi.ee, tnoges@zbi.ee \\ b Institute of Zoology and Hydrobiology, University of Tartu, Vanemuise 46, 51014 Tartu, Estonia
}

Received 28 March 2001

\begin{abstract}
In the18th and 19th centuries the first data on fisheries, hydrology, and aquatic vegetation in Lake Võrtsjärv were published by Baltic German naturalists. The comprehensive investigation by the Lake Commission of the Estonian Naturalists' Society in 1911-13 led by M. von zur Mühlen is a milestone in the scientific level. During more than 30 years after the publication of a profound monograph in 1920 by M. von zur Mühlen and G. Schneider only a few investigations were carried out on L. Võrtsjärv. The bulk of the present long-term data set on L. Võrtsjärv has been collected during the existence of the Limnological Station since the 1960s.
\end{abstract}

Key words: Lake Võrtsjärv, history of investigations, hydrology, water chemistry, hydrobiology.

\section{INTRODUCTION}

Being located far from the cradles of ancient human culture, Lake Võrtsjärv was first mentioned in the Chronicle of Henry of Livonia (Heinrici Chronicon Livoniae) only about 800 years ago. It cannot compare with e.g. much smaller Lake Kinneret Sea of Galilee in Israel, affording residental areas for Homo erectus on its shores already 1.4 million years ago, the written history of which reaches far back into antiquity, and which has figured prominently in the life of Jesus and his ministry (Berman, 1994). However, history makes curves and 80 years ago, at the time when the first profound scientific monograph on L. Võrtsjärv was published (Mühlen \& Schneider, 1920), the region of Kinneret was only roughly mapped, without paved roads or telegraph, and rampant with malaria and bandits (Berman, 1994).

Earlier overviews of the history of L. Võrtsjärv investigations have been published in Simm (1958) and Timm (1973). Information on the history of Vorrtsjärv Limnological Station and investigations can be found also in publications by Uuspõld (1968), H. Haberman (1965, 1984, 1985, 1990), and Mäemets (1971, 1981, 1985, 1991). 


\section{THE PERIOD OF BALTIC GERMAN NATURALISTS}

The first data on the fishery in L. Võrtsjärv date back to the 18th century and are documented by Hupel (1774). In the middle of the 19th century, Baer (1860) mentioned L. Võrtsjärv and the change in its fish composition along with his research on the fishery of L. Peipsi. Considering recurrent floodings, which damaged crops and threatened to destroy forests around the lake, the hydrology of L. Võrtsjärv and, especially, the outflow conditions of the Emajõgi River were studied by Sivers (1854). Grewingk (1870) regarded the increased inflow caused by melioration work in the vicinity of the lake responsible for the water level increase. A water measuring station was established at the outflow of the lake in 1876. Unfortunately, the data collected there have got lost. In his analysis of the results of a questionnaire made among local landlords Braun (1885) presented a list of 19 fish species found in L. Võrtsjärv. He also mentioned a decline in the catches of valuable fish species - pikeperch and bream - considering mainly the use of gear of minute mesh size responsible for it. Basing partially on the observations made on L. Võrtsjärv, Klinge (1890) formulated his rule of the influence of prevailing winds on aquatic vegetation.

\section{LAKE COMMISSION OF THE ESTONIAN NATURALISTS' SOCIETY}

The first comprehensive investigation of L. Võrtsjärv including geology, hydrology, hydrobiology, ichthyology, and ornithology was organized in 1911-13 by the Lake Commission of the Estonian Naturalists' Society under the leadership of M. von zur Mühlen. His nephew, a geology student L. von zur Mühlen, professors G. Schneider from Riga and K. M. Levander from Helsinki, and a student J. Kodres as an assistant participated in the field work. Bird watching was performed by $\mathrm{H}$. Walter. A two-volume monograph was planned, the first part dealing with the biota and fisheries of L. Võrtsjärv and the second with its geology and hydrology. The biological part gave a taxonomic survey of algae, vascular plants, and all animal groups from protozoa to mammals. The composition of algae, protozoa, and most of the metazooplankton was identified by K. M. Levander. M. von zur Mühlen identified vascular plants and participated together with L. von zur Mühlen in the analyses of several animal groups. Part of the samples were sent to Helsinki where identifications were made by C. Lundström (Nematocera), A. Luther (Turbellaria, Rhabdocoela), E. Nordenskjöld (Hydrachnellae), T. H. Järvi (Aranei), R. Frey (Brachycera and Heteroptera), W. Axelson-Linnaniemi (Apterygota), and Y. Vuorentaus (Coleoptera, part of Heteroptera). Besides the taxonomic overview the book includes chapters on plankton by K. M. Levander, on feeding, growth, and parasites of fishes by G. Schneider, and on lake and river fisheries by M. von zur Mühlen. Much attention was paid to the protection of the fish stock. At the beginning of World War I in 1914, the publication of the monograph was 
prohibited and the already printed sheets of the first volume were confiscated by the Russian military censor. The book (Mühlen \& Schneider, 1920) came out only after the war and its first author M. von zur Mühlen, who was killed by communists on 24 December 1918, could not see it. The second part of the monograph (Mühlen, 1918) was published in Germany.

\section{BETWEEN THE TWO WORLD WARS}

During more than 30 years only a few papers were published in which the geology (Orviku, 1939), aquatic vegetation (Pastak, 1936; Eichwald, 1939), and fisheries on L. Võrtsjärv (Reinvaldt, 1934; Reinvald, 1939, 1941; Voore, 1937, 1939; Kodres, 1921; et al.) were dealt with. The year 1921, since when daily lake levels have been recorded at the outflow of the River Emajõgi at Rannu-Jõesuu, is an essential milestone in the hydrological research of the lake. Almost the whole present network of hydrological stations for water level and runoff registration, covering the basins of the Õhne, Tarvastu, and Väike Emajõgi rivers, began to operate in the 1920 s.

\section{FIELD STATION PERIOD IN THE 1950s}

In 1951 Võrtsjärv investigations were initiated and led by Prof. H. Riikoja. The works were planned at the Institute of Zoology and Botany (IZB) of the Estonian Academy of Sciences in collaboration with the Chair of Zoology of Tartu University. Ichthyological research was directed by N. Mikelsaar, the former director of the Estonian Department of the All-Union Research Institute of Marine Fisheries and Oceanography (VNIRO), who came to IZB in 1950. The ichthyologist V. Erm and the fish parasitologist H. Tell were sent to Valma fish port where they analysed the fish provided by fishermen. During three years (1952-54), N. Schönberg, using a rowboat, collected fortnightly zooplankton samples from the lake. The results obtained from the analysis of 334 samples were only partly published in the two first volumes of Hydrobiological Researches (Simm, 1958, 1961). In 1953, IZB founded a field station on the eastern shore of L. Võrtsjärv and since then the investigations became more complex including hydrochemistry, zooplankton, benthos, and fish. Water chemistry was studied in the years $1953-54$ by Simm (1958). Samples were taken four times a year from three sampling stations, in summer 1953 also from the main inflows, and analysed for $\mathrm{pH}, \mathrm{O}_{2}$, major ions, $\mathrm{SiO}_{2}, \mathrm{NO}_{3}{ }^{-}$, inorganic dissolved $\mathrm{P}$, total $\mathrm{Fe}$, and chemical oxygen demand $\left(\mathrm{COD}_{\mathrm{Mn}}, \mathrm{COD}_{\mathrm{Cr}}\right)$. Õ. Tõlp collected material for a survey on chironomid fauna (Simm, 1958). She identified altogether 51 species and larval forms in 388 samples collected in 1953-54. 


\section{VÕRTSJÄRV LIMNOLOGICAL STATION}

With the foundation of Võrtsjärv Limnological Station, a modern research centre of institute dimensions, in 1961 (main building in 1963) a qualitatively new period in the investigations began, characterized by all-the-year-round hydrochemical and hydrobiological monitoring and several large projects in planktonology, ichthyology, production biology, and taxonomy. Up to the end of the 1980s, ichthyological research had a clear priority at the Station. Despite several publications in planktology and benthology written in these years by S. Lokk, R. Laugaste, J. Haberman, T. Timm, V. Timm, and K. Kangur, the hydrochemical as well as the biological investigations served mainly as a background for ichthyology.

L. Võrtsjärv is one of the few lakes in the world having a continuous monthly data set of more than 35 years. In 1994 L. Võrtsjärv was included into the Data Book of World Lake Environments by ILEC (Kira, 1994). An overview of existing data on L. Võrtsjärv is given in Table 1.

Several monographs have been published on L. Võrtsjärv summarizing the results at different stages of investigations. Nearly 40 years had passed, however, from the first monograph by Mühlen \& Schneider (1920) until Hydrobiological Researches I (Simm, 1958) came out, which could conditionally be called the second L. Võrtsjärv monograph as it includes eight papers concerning the lake. The book included a physico-geographic overview and investigation history by E. Varep. First summaries of their work were published by H. Simm, Õ. Tõlp, I. Lissenko, N. Schönberg, Õ. Pahkla, E. Pihu, and H. Tell.

In 1973 the most voluminous monograph Vortsjärv (Timm, 1973) was published, which summarized the investigations made up to 1967. Surveys on the geology of the lake depression (K. Orviku), the geology and distribution of bottom sediments (K. Veber), hydrology (A. Jaani), and hydrochemistry (H. Starast, H. Simm) are included. In the biological part the aquatic vegetation (Aime Mäemets), bacteria (S. Lokk), algae (M. Pork, V. Kõvask), zooplankton (J. Haberman, Aare Mäemets), zoobenthos (H. Riikoja, J. Ristkok, K. Ruse, T. Timm, V. Timm, Õ. Tõlp), fishes and fisheries (H. Haberman, M. Kangur, A. Kirsipuu, A. Luts, N. Mikelsaar, Evi and Ervin Pihu, H. Tell), and bird fauna of the lake (O. Renno) are discussed. The taxonomic list of plant and animal species found in L. Võrtsjärv by that time is of particular value.

Proceedings of the conference dedicated to the 30th anniversary of Võrtsjärv Limnological Station was published as a monographic collection of papers (Haberman, J., 1984) entitled Võrtsjärve ökosüsteemi seisund (State of the ecosystem of Lake Võrtsjärv). It summarized the past 10 years of hydrochemical and biological monitoring but included also papers on geology, ichthyology, fisheries, and history of human settlement.

Supported by G. Soros Foundation the digitalizing of data collected during the existence of Võrtsjärv Limnological Station was completed in 1993. A set of 14 papers summarizing the 30 -year investigations was published in a special issue of 
Table 1. Hydrological and hydrobiological measurements carried out in L. Võrtsjärv since the 1950s

\begin{tabular}{|c|c|c|c|}
\hline Parameter & $\begin{array}{c}\text { Continuous } \\
\text { monthly } \\
\text { measurements }\end{array}$ & $\begin{array}{l}\text { Annual or seasonal } \\
\text { measurements }\end{array}$ & $\begin{array}{l}\text { Rare or single } \\
\text { measurements }\end{array}$ \\
\hline \multicolumn{4}{|l|}{ Hydrochemistry } \\
\hline $\mathrm{O}_{2}$ & $1968 \ldots$ & $1953-54,1960-90^{*}$ & \\
\hline $\mathrm{pH}$ & $1968 \ldots$ & $1953-54,1960-90^{*}$ & \\
\hline $\mathrm{HCO}_{3}^{-}$ & $1968 \ldots$ & $1953-54,1960-90 *$ & \\
\hline Other major ions & $1989 \ldots$ & $1953-54,1960-90 *$ & \\
\hline $\mathrm{PO}_{4}-\mathrm{P}$ & $1968 \ldots$ & $1953-54,1960-90^{*}$ & \\
\hline $\mathrm{NO}_{3}-\mathrm{N}$ & $1968 \ldots$ & $1953-54,1960-90^{*}$ & \\
\hline $\mathrm{COD}_{\mathrm{Cr}}$ & $1968 \ldots$ & $1953-54,1960-90 *$ & \\
\hline $\mathrm{COD}_{\mathrm{Mn}}$ & $1968 \ldots$ & $1953-54,1960-90 *$ & \\
\hline Total $\mathrm{N}$ and $\mathrm{P}$ & $1982 \ldots$ & & \\
\hline $\mathrm{Si}$ & $1992 \ldots$ & $1953-54$ & \\
\hline Total suspended solids & $1989 \ldots$ & $1983-84$ & \\
\hline Sediment chemistry & & & $1968,1994-97$ \\
\hline Heavy metals $(\mathrm{Hg}, \mathrm{Zn}, \mathrm{Cu})$ & & & 1986 \\
\hline $\mathrm{PAHs}$ & & & 1976-77; 1995 \\
\hline \multicolumn{4}{|l|}{ Microbiology } \\
\hline Total count of bacteria & $1963 \ldots$ & & \\
\hline Saprophytic bacteria & $1963 \ldots$ & & \\
\hline Aerobic and anaerobic saprophytes & & $1963-65$ & \\
\hline Proteolytic bacteria & & $1963-65$ & \\
\hline Amylolytic bacteria & & $1963-65$ & \\
\hline Spore forming bacteria & & $1963-65$ & \\
\hline Bacteria in sediments & & 1963-65 & \\
\hline Coli index & & $1977-80,1993$ & \\
\hline \multicolumn{4}{|l|}{ Bacterial production } \\
\hline counting method & & $1981-82$ & \\
\hline${ }^{3} \mathrm{H}$-thymidine method & $1991 \ldots$ & & \\
\hline${ }^{3} \mathrm{H}$-leucine method & & 1993-94 & \\
\hline $\mathrm{BOD}_{7}$ & $1993 \ldots$ & & \\
\hline \multicolumn{4}{|l|}{ Phytoplankton } \\
\hline Species composition & $1964 \ldots$ & & \\
\hline Biomass & $1964 \ldots$ & & \\
\hline Chlorophylls $a, b, c$ & $1982 \ldots$ & & \\
\hline Phaeopigments & $1982 \ldots$ & & \\
\hline Carotenoids & $1988 \ldots$ & & \\
\hline \multicolumn{4}{|l|}{ Primary production } \\
\hline oxygen method & & $1970-72$ & \\
\hline${ }^{14} \mathrm{C}$ method & $1995 \ldots$ & 1982-84, 1989, 1991 & \\
\hline ATP content & & 1986-87, 1991 & \\
\hline Sedimentation rate & & $1989,1995-96$ & \\
\hline Picoplankton abundance & & 1998-2000 & \\
\hline Picoplankton production & & 1998-2000 & \\
\hline
\end{tabular}


Table 1 continued

\begin{tabular}{c|c|c|c}
\hline Parameter & $\begin{array}{c}\text { Continuous } \\
\text { monthly } \\
\text { measurements }\end{array}$ & $\begin{array}{c}\text { Annual or seasonal } \\
\text { measurements }\end{array}$ & $\begin{array}{c}\text { Rare or single } \\
\text { measurements }\end{array}$ \\
\hline
\end{tabular}

\section{Metazooplankton}

Species composition

Biomass

Production

Grazing

\section{Protozooplankton}

Species composition

Biomass

Aquatic macrophytes

Species composition

Colonization pattern

Biomass

Production

Calorific value

\section{Macrozoobenthos}

Species composition

Population density by groups

Total biomass by groups

Biomass of individual species

Calorific value

Production

Macrozoobenthos of the littoral

Macrozoobenthos of the inflows

\section{Background data}

Water temperature

Water level

Transparency

Water colour $\begin{array}{ll}1965 \ldots & 1952-54 \\ 1965 \ldots & 1952-54\end{array}$

$1984 \ldots$

$1984-85,1998,2000$

1995.

$1995 \ldots$

$\begin{array}{ccc} & & 1965-67,1997 \\ & & 1965-67,1997 \\ 1995 \\ & & 1995 \\ & & 1995 \\ & & \\ 1965 \ldots & 1964 & 1953-55 \\ 1965 \ldots & 1964 & 1953-55 \\ 1965 \ldots & 1964 & 1953-55 \\ 1973 \ldots & 1993-94 & \\ & & \\ & & \\ & 1973-75,1982-84, & \\ & 1989,1991,1993 & \\ & 1965 \ldots \text { every } 5 \text { years } & 1959-60\end{array}$

$1921 \ldots *$

$1921 \ldots *$

$1960 \ldots$

$1960 \ldots$

* Measurements made by the Hydrometeorological Service.

the journal Limnologica (Nõges, 1998). In comparison with earlier monographs, a characteristic feature of this collection is a more interrelated approach between different fields of investigation. Budgets of substances were calculated on the basis of hydrochemical and runoff data, food web structure and feeding relations were analysed, and several statistical relationships were revealed between the biota and abiotic factors.

The cooperation between Pirkanmaa Regional Environment Centre, Finnish Environment Institute, Võrtsjärv Limnological Station, and the University of Tartu in the years 1993-97 resulted in the description of the ecological state and hydrodynamic and ecological modelling of the lake (Huttula \& Nõges, 1998). 


\section{Hydrological investigations}

Altogether three hydrographic surveys have been made on L. Võrtsjärv: in 1913, 1956, and in the early 1980s. The original map with plumbing data of the first survey was confiscated by the Russian military censor and got lost during World War I. Riikoja (1930) restored the bathymetric data on the basis of a photocopy of a 1:42000 map saved by chance by J. Kodres. The second sounding of the lake was performed by the Board of Hydrometeorological Service of the Estonian SSR in 1956 and the data form the basis for hydrological calculations up to now. Because of the rapid sediment accumulation in the lake, especially in its southern part, a correction would be needed. The last survey of the lake was carried out from the ice according to a $50 \times 50 \mathrm{~m}$ grid in the first half of the 1980 s by the Central Board of Geodesy and Cartography of the USSR. Unfortunately, no corrections for the changes in the water level were made to the map resulting in a mismatch of isobaths on different sheets.

Daily measurements of water level and runoff made by the hydrological station established at the outflow at Rannu-Jõesuu in 1921 form a solid basis for hydrological investigations. The most profound summary covering the period of 1921-66 was written by A. Jaani (Timm, 1973). Basing on measurements made at the hydrological station in Tartu, Jaani (1990) reconstructed the water levels back to the year 1885 and demonstrated the existence of a periodicity in the data series with a period length of about 30 years. In the 1970s, a heated discussion on the use of water resources of L. Võrtsjärv arose between Eipre (1971) and Mäemets (1972). Supporting water level regulation, Eipre considered L. Võrtsjärv as an almost unlimited source of water, which could be used for the water supply of the towns of Tõrva, Mustla, Viljandi, Jõgeva, and Põltsamaa. Mäemets, although admitting the need for preventing low water levels by regulation, pointed to several possible dangers to the fisheries, water quality, and water flow in the Emajõgi due to a large-scale hydrological rearrangement. The low-water period at the beginning of the 1970s was the cause why a regulation scheme of L. Võrtsjärv was worked out. A number of water level regulation scenarios were computer-simulated by Kaljumäe \& Koskor (1980) and an optimum scheme was selected, on whose basis a sluice regulator was designed. For several reasons the plan was not realized. Recent changes in the hydrological regime were described by Järvet (2000a). Causal relations between the water regime and ecological state of the lake have been discussed by Nõges \& Nõges $(1998,1999)$ and by Järvet (2000b). A new version of a sluice regulator was designed by hydrologists from Pirkanmaa Regional Environment Centre (Bilaletdin \& Arvonen, 1999). In cooperation with the above-mentioned institution in 1993-97, the current system of the lake was measured, and a 2-dimensional flow model as well as a particle tracking model were created for L. Võrtsjärv (Huttula \& Nõges, 1998). 


\section{Hydrochemical investigations}

First data on chemical properties of the water in L. Võrtsjärv originate from the measurements by $\mathrm{H}$. Simm. The Tiirikoja Lake Station of the Board of the Hydrometeorological Service started regular sampling in 1960. A profound survey of the chemical regime of the lake with an emphasis on the functioning of the carbonate buffering system was written by H. Starast and H. Simm (Timm, 1973). Regular chemical monitoring at Võrtsjärv Limnological Station carried out by M. Parts, T. Koemets, and R. Tiidor was launched in 1968. Up to the 1990s there were no separate projects on hydrochemistry and chemical data were mainly used as background information in hydrobiological studies. A few papers were published on nutrient dynamics (Starast, 1982), carcinogenic content of plants (Veldre et al., 1982), and changes in ionic composition (Nõges, 1992). Since 1989 the major part of hydrochemical analyses have been performed at the South Estonian Environmental Protection Laboratory (present Tartu Environmental Research Ltd.). Results of nutrient budget calculations and sediment phosphorus investigations carried out in the 1990s by P. and T. Nõges, A. Kisand, L. Tuvikene, and A. Järvet have been published in two recent monographs (Nõges, 1998; Huttula \& Nõges, 1998).

\section{Plankton investigations}

Bacterioplankton studies in L. Võrtsjärv were initiated in 1963 by S. Lokk. She counted the total number of bacteria on erythrosine-stained filters and the numbers of some saprophytic groups. Helmi Tammert continued the work in the 1970s and V. Kisand in the 1990s. A summary of the first 20-year monitoring period was written by S. Lokk and H. Tammert (Haberman, J., 1984) and the following 10-year period was analysed by V. Kisand and H. Tammert (Nõges, 1998). Recent decades have witnessed a rapid development of research methods in microbiology. The introduction of fluorescent staining, radioactive methods in bacterial activity measurements and exoenzyme (alkaline phosphatases, glycosidases, peptidases) activity measurements were initiated by T. Nõges and V. Kisand in the 1990s.

Phytoplankton was not studied in L. Võrtsjärv in the 1950s and its regular sampling started only in 1964. M. Pork and V. Kõvask identified altogether 518 algal taxa (Timm, 1973). Their work has remained the only one up to now that discusses also epiphyton and phytobenthos of L. Võrtsjärv. During the following 11 years (1968-79), phytoplankton was analysed by R. Laugaste. She made the first primary production measurements (Laugaste, 1975) and analysed the composition and dynamics of winter phytoplankton (Laugaste, 1978). Since 1979 the phytoplankton in routine samples has been counted by P. Nõges. The long-term changes in phytoplankton from the 1960s until the 1990s were discussed by P. Nõges and R. Laugaste (Nõges, 1998). Since 1982 biomass countings are complemented with chlorophyll measurements, primary production measurements using ${ }^{14} \mathrm{C}$ technique, and ATP measurements. Within the frames of the project "Factors 
controlling growth and composition of phytoplankton in L. Võrtsjärv" (1995-99, led by T. Nõges), L. Tuvikene investigated experimentally nutrient limitation of phytoplankton, I. Tõnno measured nitrogen fixation by cyanobacteria, and T. Reisenbuk measured the abundance and activity of autotrophic picoplankton.

Some zooplankton samples from the years 1954-66 were analysed by Aare Mäemets, but regular sampling was started in 1965 by J. Haberman. The ecology and seasonal dynamics of different zooplankton groups in L. Võrtsjärv have been treated in a large number of papers. The most comprehensive survey is given in Nõges (1998). Besides time-consuming monitoring work J. Haberman has been interested in the influence of detritus on cladocerans, the indicator value of different species, and in the energy budget of zooplankton. Cladoceran grazing in L. Võrtsjärv was studied in 1984-85 by T. Nõges, who summarized also the results of food web analysis (Nõges, 1998). In recent years, zooplankton has been studied by A. Põllumäe and H. Künnap. In 1995 P. Zingel started investigations on protozooplankton, a group that had been earlier studied only by K. M. Levander (Mühlen \& Schneider, 1920) and that proved to have at least as high ecological significance in L. Võrtsjärv as metazooplankton (Zingel, 1999).

\section{Aquatic macrophyte investigations}

The most profound description of the species composition and colonization pattern in L. Võrtsjärv was given by Aime Mäemets (Timm, 1973). In 1997, Tõnu Feldmann defended his MSc thesis on the distribution of aquatic plants in L. Võrtsjärv and the controlling factors.

\section{Macrozoobenthos investigations}

The basic knowledge about macroinvertebrate fauna of L. Võrtsjärv as of 1968 was summarized in the monograph Vortsjärv (Timm, 1973). Since the 1950s, Õ. Tõlp had identified 70 forms of chironomid larvae; 42 oligochaete and 46 mollusc taxa had been described in the lake. Following investigations have essentially prolonged the list. An overview by K. Kangur, H. Timm, T. Timm, and V. Timm (Nõges, 1998) refers to 150 species and larval forms of Chironomidae, 70 species of Mollusca, and 54 species of Oligochaeta in the lake. Since 1973 the chironomid investigations have been performed by K. Kangur. Surveys by taxonomic groups have been published in two monographs (Timm, 1973; Haberman, J., 1984). H. Timm joined the group later and has been responsible for analysing the animals gathered to the "varia" group, of which overviews have been published on Hydracarina (Hydrachnellae) by I. Lissenko (Simm, 1958), on Heleidae by Maasik (1966), and on Trichoptera by Kachalova (1980). One of the most valuable outputs of benthos investigations has been the formation of a longterm data series. The analysis made by the benthos working group has revealed the 
existence of considerable trends and periodicities within animal groups. These have been attributed to climatic conditions, especially solar activity (Timm, 1975), and biotic factors such as food and predation.

\section{Ichthyological and fishery research}

Since the 1950s and especially after the foundation of the Limnological Station, comprehensive research started on the fishery in L. Vorrtsjärv resulting in publications on ichthyophenology (J. Ristkok), production biology (T. Noorits), growth and age structure (H. Haberman, Ervin Pihu, M. Kangur, Andu Kangur, A. Järvalt), feeding (Ervin and Evi Pihu, Andu Kangur, K. Kangur, M. Kangur, P. Kangur), parasites (E. Ridala, H. Tell, Andu Kangur), and migration of fish (H. Haberman, A. Järvalt). Contributions by M. Kangur, Ervin Pihu, N. Mikelsaar, and $\mathrm{H}$. Haberman created principles for changing the arrangement of fishing in L. Võrtsjärv thoroughly. Implementation of these principles in the 1970s resulted in L. Võrtsjärv losing its left-handed celebrity as a ruffe lake, whereas its fish composition improved and catches stayed on high levels. Several papers on population dynamics and ecology have been published by H. Haberman (bream, perch), Andu Kangur (eel, ruffe), V. Erm (pikeperch), Ervin Pihu (pike, perch, ruffe), M. Kangur (ruffe). Until the 1990s, the problems of productive-biological traits (H. Haberman, A. Kirsipuu, K. Laugaste), blood physiology (A. Kirsipuu), muscle biochemistry (Alla Kangur), energy content (L. Tuvikene), hepatic histology (K. Laugaste), and genetics of fish (T. Paaver) were actively dealt with. At the beginning of the 1990s, A. Tuvikene initiated studies in fish toxicology.

Overviews on fish composition in L. Võrtsjärv have been published in three monographs (Timm,1973; Haberman, J., 1984; Nõges, 1998) and a large number of articles. A synopsis of ichthyological investigations in L. Võrtsjärv is presented in Table 2 .

\section{Bird fauna}

Bird fauna of L. Võrtsjärv has been studied episodically. The only published data are the notes by H. Walter, L. von zur Mühlen, and G. Schneider (Mühlen \& Schneider, 1920), the review by O. Renno (Timm, 1973), and results of cormorant watching by Kaljuste (1995).

\section{ACKNOWLEDGEMENTS}

The preparation of this paper was supported by the Estonian Science Foundation (grant No. 4080). The authors are grateful to Dr. Tarmo Timm for advice and critical reading of the manuscript. 
Table 2. Chronology of ichthyological and fisheries investigation in L. Võrtsjärv since the 1950s

\begin{tabular}{|c|c|c|c|c|c|c|c|c|c|}
\hline Fish species & $\begin{array}{l}\text { Morphometric } \\
\text { characteristics }\end{array}$ & $\begin{array}{l}\text { Sexual } \\
\text { cycle }\end{array}$ & Spawning & Fecundity & Feeding & $\begin{array}{l}\text { Growth } \\
\text { rate }\end{array}$ & Parasites & $\begin{array}{c}\text { Physiol. \& biochem. } \\
\text { characteristics }\end{array}$ & $\begin{array}{l}\text { Stock, } \\
\text { protection }\end{array}$ \\
\hline Coregonus albula & & & & $1952-70$ & $1952-53$ & $1952-53$ & $1952-67$ & $1969-70$ & $1967-70$ \\
\hline Osmerus eperlanus & & & & 1967 & $1966-70$ & 1966 & $1952-67$ & $1969-71$ & $1967 \ldots$ \\
\hline Esox lucius & 1958 & $1955-58$ & $1955-58$ & $1955-58$ & $1951 \ldots$ & $1951 \ldots$ & $1952-83$ & & $1966 \ldots$ \\
\hline Anguilla anguilla & 1993 & & & & $1966 \ldots$ & $1974 \ldots$ & $1993 \ldots$ & $1974-78$ & $1974 \ldots$ \\
\hline Leuciscus idus & $1964-80$ & $1955-58$ & $1955-58$ & $1955-58$ & & $1974-58$ & $1952-67$ & 1970 & \\
\hline Aspius aspius & & & & 1966 & 1998 & $1956-64$ & $1952-67$ & & \\
\hline Rutilus rutilus & $1955-56$ & $1955-58$ & $1955-58$ & $1955-58$ & $1966-70$ & $1954-58$ & $1952-67$ & $1969-71$ & $1966-70$ \\
\hline Scardinius erythrophthalamus & $1964-70$ & $1955-58$ & $1955-58$ & $1955-58$ & & $1954-58$ & $1952-67$ & $1969-77$ & \\
\hline Abramis brama & $1959-61$ & $1955-58$ & $1955-80$ & $1956-61$ & $1959 \ldots$ & $1954 \ldots$ & $1952-83$ & $1961-89$ & $1959 \ldots$ \\
\hline Blicca bjoerkna & & $1952-58$ & $1955-58$ & $1955-58$ & & $1955-82$ & $1952-67$ & $1970-71$ & $1978 \ldots$ \\
\hline Carassius carassius & & $1955-58$ & $1955-58$ & $1955-58$ & & $1955-58$ & $1952-54$ & & \\
\hline Tinca tinca & $1964-82$ & $1952-58$ & $1955-58$ & $1955-58$ & & $1955-76$ & $1952-54$ & & \\
\hline Alburnus alburnus & & & $1955-58$ & $1955-58$ & & & $1952-67$ & & $1978 \ldots$ \\
\hline Cobitis taenia & & & & & & & $1952-67$ & & \\
\hline Lota lota & $1980-81$ & & & $1967-68$ & $1951 \ldots$ & $1966 \ldots$ & $1952-68$ & & $1966 \ldots$ \\
\hline Lucioperca lucioperca & $1952-54$ & & $1952-54$ & $1952-54$ & $1951 \ldots$ & $1951 \ldots$ & $1952-68$ & $1972-90$ & $1966 \ldots$ \\
\hline Perca fluviatilis & & $1955-58$ & $1955-58$ & $1955-58$ & $1951 \ldots$ & $1966 \ldots$ & $1952-68$ & $1969-93$ & $1964 \ldots$ \\
\hline Gymnocephalus cernuus & $1992 \ldots$ & & $1955-58$ & $1955-58$ & $1959 \ldots$ & $1966 \ldots$ & $1952-67$ & $1969-71$ & $1966 \ldots$ \\
\hline Gottus gobio & & & & 1967 & 1967 & 1967 & & $1970-71$ & \\
\hline
\end{tabular}




\section{REFERENCES}

Baer, K. E. von. 1860. Investigations on the State of Fisheries in Russia. Vol. 1. Fisheries in Lakes Peipsi and Pskov and in the Baltic Sea. Sankt Peterburg (in Russian).

Berman, T. 1994. The Kinneret - Sea of Galilee. Ariel, 98, 1-13.

Bilaletdin, Ä. \& Arvonen, H. (eds.) 1999. Võrtsjärven kunnostuksen ja suojelun yleissuunnitelma. Suomen Ympäristö, 374.

Braun, M. 1885. Die Fischereiverhältnisse in Livland. Mittheilungen der Livländischen Abtheilung der Russischen Gesellschaft für Fischzucht und Fischfang. I. Sonderabdruck aus der baltischen Wochenschrift, Dorpat.

Eichwald, K. 1939. Taimkate. In Viljandimaa. Tartu.

Eipre, T. 1971. Eesti mageveevarud ja veeolude reguleerimine. 1. Eesti Loodus, 9, 549-555.

Grewingk, C. 1870. Über Eisschiebung am Wörz-Järw-See in Livland. Archiv für die Naturkunde Liv-, Est- und Kurlands. I Ser., V Band, 1. Lief., 1-24. Dorpat.

Haberman, H. 1965. Võrtsjärve Limnoloogiajaam - uus hüdrobioloogiline uurimiskeskus. Eesti Loodus, 4, 193-197.

Haberman, H. 1984. Zooloogia ja Botaanika Instituudi Võrtsjärve Limnoloogiajaam kolmekümneaastane. In Võrtsjärve ökosüsteemi seisund (Haberman, J., ed.), pp. 5-10. Tartu.

Haberman, H. 1985. Noorus on läbi. Eesti Loodus, 3, 179-182.

Haberman, H. 1990. Võrtsjärv mu arm. Eesti Loodus, 11, 693-696.

Haberman, J. (ed.) 1984. Võrtsjärve ökosüsteemi seisund. Tartu.

Hupel, W. 1774. Topographische Nachrichten von Lief- und Ehstland, 1. Riga.

Huttula, T. \& Nõges, T. (eds.) 1998. Present state and future fate of Lake Võrtsjärv. The Finnish Environment, 209.

Jaani, A. 1990. Võrtsjärve veerežiim ja -bilanss. Eesti Loodus, 11, 743-747.

Järvet, A. 2000a. Water regime of Lake Võrtsjärv. In Estonia. Geographical Studies, 8 (Kaare, T. \& Punning, J.-M., eds.), pp. 72-88. Est. Acad. Publ., Tallinn.

Järvet, A. 2000b. Hüdroloogilised tingimused Võrtsjärve ökoloogilise režiimi kujundajana. Keskkonnatehnika, 5, 36-38.

Kachalova, O. 1980. Caddisflies in the Lakes Peipus-Pskov and Võrtsjärv. In Hydrobiological Researches, Vol. 9 (Pihu, E., ed.), pp. 87-97. Tallinn (in Russian).

Kaljumäe, H. \& Koskor, I. 1980. Võrtsjärve veerežiimi reguleerimise võimalustest. In Eesti NSV pinnavete kasutamine ja kaitse (Mäemets, A., ed.), pp. 104-114. Valgus, Tallinn.

Kaljuste, O. 1995. Kormoranide ebakoloonia Võrtsjärvel. Eesti Loodus, 2, 46-47.

Kira, T. (ed.) 1994. Data Book of World Lake Environments - a Survey of the State of World Lakes. 2. Africa and Europe. International Lake Environment Committee, United Nations Environment Programme, Kusatsu.

Klinge, J. 1890. Über den Einfluss der mittleren Windrichtung auf das Verwachsen der Gewässer nebst Betrachtung anderer von der Windrichtung abhängiger Vegetations-Erscheinungen im Ostbalticum. Botanische Jahrbücher für Systematik, Pflanzengeschichte und Pflanzengeographie, herausgegeben von A. Engler, 11, 264-313. Leipzig.

Kodres, J. 1921. Kalapüük mutiga Võrtsjärves. Kalaasjandus, 3, 32-33.

Laugaste, R. 1975. Productivity of phytoplankton in Lake Võrtsjärv in 1970-1972. In Productivity of Estonian Water Bodies. Estonian Contributions to the IBP. Progress Report, 6, pp. 161164. Tartu.

Laugaste, R. 1978. The winter phytoplankton of L. Võrtsjärv. In Hydrobiological Researches, Vol. 7, pp. 7-19 (in Russian).

Maasik, I. 1966. Andmeid Võrtsjärve habesääsklaste (Diptera, Heleidae) faunast ja ökoloogiast. TRÜ toimetised, 180.

Mäemets, A. 1971. Estonian Limnology. Valgus, Tallinn.

Mäemets, A. 1972. Veel mageveevarudest ja nende kasutamisest. Eesti Loodus, 8, 449-455.

Mäemets, A. 1981. Järveuurimise kroonika 1951, 1. Eesti Loodus, 3, 156-161. 
Mäemets, A. 1985. Neeme Mikelsaar - etapp Eesti järveuurimises. Eesti Loodus, 9, 604-605.

Mäemets, A. 1991. Kuidas kõik see algas. Eesti Loodus, 10, 606-609.

Mühlen, L. von zur. 1918. Zur Geologie und Hüdrologie des Wirtsjerwsees. Abhandlungen der Königlichen Preussischen Geologischen Landesanstalt, Neue Folge, 13. Berlin.

Mühlen, M. von zur. \& Schneider, G. 1920. Der See Wirzjerw in Livland. Archiv für die Naturkunde des Ostbaltikums, 14.

Nõges, P. 1992. Changes in the ionic composition of L. Võrtsjärv (Estonian Republic). Limnologica, 22, 115-120.

Nõges, P. (ed.) 1998. Limnology of Lake Võrtsjärv. Limnologica, 28.

Nõges, P. \& Nõges, T. 1998. The effect of fluctuating water level on the ecosystem of Lake Võrtsjärv, Central Estonia. Proc. Estonian Acad. Sci. Biol. Ecol., 47, 98-113.

Nõges, T. \& Nõges, P. 1999. The effect of extreme water level decrease on hydrochemistry and phytoplankton in a shallow eutrophic lake. Hydrobiologia, 409, 277-283.

Orviku, K. 1939. Viljandimaa aluspõhi ja pinnakate. In Viljandimaa, pp. 10-22. Tartu.

Pastak, E. 1936. Võrtsjärve idaranniku taimkattest. Eesti Loodus, 4, 137-140.

Reinvaldt, E. 1934. Võrtsjärve rääbisest. Kalandus, 1, 21-24.

Reinvald, E. 1939. Kalade suremisest Võrtsjärves 1939. a. kevadel. Eesti Kalandus, 8/9, 212-214.

Reinvald, E. 1941. Märkmeid kalade paigutamisest Eesti NSV ala veekogudesse. Loodusuurijate Seltsi Aruanded, 47, 41-48.

Riikoja, H. 1930. Zur Morphometrie einiger Seen Eestis. Loodusuurijate Seltsi Aruanded, 37, 115-201.

Simm, H. (ed.) 1958. Hydrobiological Researches, I. Tartu (in Russian).

Simm, H. (ed.) 1961. Hydrobiological Researches, II. Tartu (in Estonian).

Sivers, G. 1854. Die Flussfahrt auf dem Embach vom dessen Ausfluss aus dem Wirzjärv bis Dorpat. Archiv für die Naturkunde Liv-, Ehst- und Kurlands, Serie I, 1, 353-366.

Starast, H. 1982. Fosfaadi- ja nitraadisisalduse dünaamika seaduspärasused Võrtsjärve vesikonnas. In Eesti NSV järvede nü̈̈disseisund (Simm, H., ed.), pp. 26-31. Tartu.

Timm, T. (ed.) 1973. Võrtsjärv. Valgus, Tallinn.

Timm, T. 1975. Zoobenthos of Lake Võrtsjärv in 1964-1972. In Productivity of Estonian Water Bodies. Estonian Contributions to the IBP. Progress Report, 6, pp. 165-200. Tartu.

Uuspõld, L. 1968. Põgus pilk Limnoloogiajaama. Eesti Loodus, 5, 308.

Veldre, I., Itra, A. \& Paalme, L. 1982. Veetaimed - järve kantserogeense saastumise indikaatorid. In Eesti NSV järvede nüüdisseisund (Simm, H., ed.), pp. 125-133. Tartu.

Voore, V. 1937. Linnuronist. Eesti Kalandus, 8, 210-213.

Voore, V. 1939. Andmeid Eesti kalade parasiitidest. Eesti Kalandus, 8/9, 201-211.

Zingel, P. 1999. Pelagic ciliated protozoa in a shallow eutrophic lake: Community structure and seasonal dynamics. Arch. Hydrobiol., 146, 495-511.

\section{VÕRTSJÄRVE HÜDROLOOGILISE JA BIOLOOGILISE UURIMISE AJALUGU}

\section{Peeter NÕGES, Andu KANGUR, Ain JÄRVALT ja Tiina NÕGES}

Ehkki üksikuid tähelepanekuid Võrtsjärve morfomeetria ja kalastiku kohta ilmus juba 18. sajandil, võib järve teaduslikust uurimisest tõsiselt rääkima hakata alles seoses 20. sajandi teisel kümnendil tehtud kompleksuurimisega. Selle korraldas aastatel 1911-1913 Tartu Ülikooli juures asuv Eesti Loodusuurijate Seltsi järvekomisjon oma esimehe M. von zur Mühleni eestvõtmisel. Nende tööde 
põhjal ilmunud kaheosaline monograafia (Mühlen, 1918; Mühlen \& Schneider, 1920) kui järve suhteliselt puutumatu seisundi kirjeldus ei ole minetanud oma tähtsust tänapäevani. 1921. aastast Rannu-Jõesuus igapäevaselt mõõdetud järve veetasemed on hüdroloogilise andmebaasi selgroog ja selle aegrea uurimine on andnud väärtuslikku teavet meie kliima trendide ja perioodiliste muutuste kohta. Kahe maailmasõja vahelisel ajal ilmus üksikuid uurimusi Võrtsjärve geoloogia, kõrgema veetaimestiku ja kalastiku alalt, kuid kompleksseid töid ei korraldatud. Järve uuringud algasid uue hooga 1950. aastate algul Tartu Ülikooli ja Teaduste Akadeemia Zooloogia ja Botaanika Instituudi (ZBI) koostöös, kus eestvedajateks olid professorid H. Riikoja ja N. Mikelsaar. Neil aastatel uuriti põhjalikult Võrtsjärve hüdrokeemiat, zooplanktonit, põhjaloomastikku ja kalastikku. Vaatluse alt jäid välja fütoplankton ja kõrgem veetaimestik. ZBI Võrtsjärve Limnoloogiajaama rajamisega (selle esimene labor tegutses 1961. aastast kuni peahoone valmimiseni 1963. aastal elumajas) said võimalikuks järve aastaringsed uuringud. 1960. aastatest alguse saanud hüdrobioloogiliste ja hüdrokeemiliste andmeridade väärtus on aastast aastasse kasvamas. Limnoloogiajaam on oma töödes säilitanud peamiselt väliuuringutel põhineva ökoloogilise suuna. Võrtsjärve senised uuringud on kokku võetud paljudes artiklites ja monograafiates (Timm (toim.), 1973; Haberman (toim.), 1984; Nõges (toim.), 1998; Huttula \& Nõges (toim.), 1998). Viimase aja uutest töösuundadest võiks nimetada planktiliste algloomade uuringuid ning koostöös Soome teadlastega tehtud töid järve setete, hüdrodünaamika ja ökoloogilise modelleerimise alal. 